\title{
Study on the Accumulation of Metallic Component into Anodic Graphite for Caustic Chlorine Cell
}

\author{
Osamu Suzuki*, Tomio Fukunaga* and Kazuo Takahashi*
}

\section{Introduction}

It is commonly known in the recent electrolytic soda industry, especially in the mercury method, that the existence of heavy metals impurities, such as vanadium, chromium, iron, etc. results in operational disadvantages at the time of electrolysis, either by generating a considerable quantity of hydrogen gas from the mercury cathode to drop the current efficiency, or by forming an explosive gas, which after mixing with the chlorine gas generated form the anode.

Several reports have been presented concerned with the material balance between these metallic substances in the mercury method. ${ }^{\left.1{ }^{2}\right)}$ But few studies have been made on the influence of heavy metals impurities on the diaphragm electrolytic cell.

One of the principal results obtaind by the authors, by means of an Allen Moore KML-type electrolytic cell, is the gradual accumulation of the metallic components into the anodic graphite.

In order to pursuit the action of the metallic components in the anodic graphite, the gradual accumulation quantity was measured in the course of electrolysis by continuous adding of very small quantity of cobalt chloride, as a heavy metallic ion to the saturated sodium chloride solution that is to be delivered to the electrolytic cell.
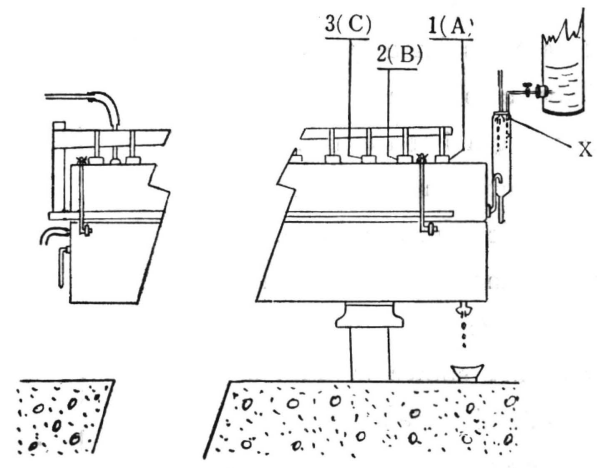

Fig. 1 Schematic drawing of the electrolytic cell.

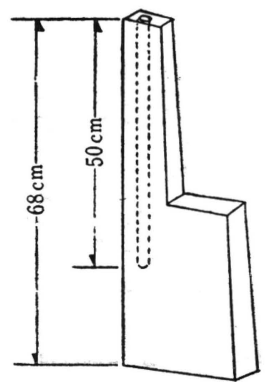

Fig. 2 Spot where samples for analysis have been taken.

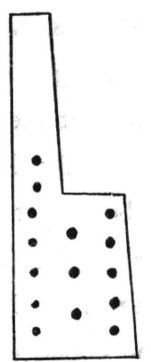

Fig. 3 Rough sketch of drilled graphite.

* Tsurumi Soda Co. Ltd., 1-7 Suehiro-cho, Turumiku, Yokohama City, Japan.

The original written in Japanese can be seen in J. Flectrochem. Soc. Japan 28, 100 (1960). 
Table 1 Properties of Graphites

\begin{tabular}{c|c|c|c|c}
\hline \hline Maker & $\begin{array}{l}\text { Apparent specific } \\
\text { gravity }\end{array}$ & True specific gravity & Porosity (\%) & Ash (\%) \\
\hline A & 1.71 & 2.18 & 21.6 & 0.09 \\
B & 1.59 & 2.20 & 27.9 & 0.08 \\
C & 1.61 & 2.20 & 0.10 & \\
\hline
\end{tabular}

\section{Method of experiments}

The Allen Moore KML-type electrolytic cell ${ }^{3)}$ has 3 graphite plates with holes of about $1.4 \mathrm{~cm}$ diameter and about $50 \mathrm{~cm}$ length as shown in Fig. 1 and Fig. 2.

The anodic solution were collected from the holes and analysed according to operation days. The holes were filled by rubber plugs having a small hole to maintain the atmospheric pressure and to minimize the evaporation of the solution accumulated in the holes.

The specification of the graphite used in this experiment was given in the Table 1.

Cobalt added to the saturated sodium chloride solution was applied after having been made $0.01 \%$

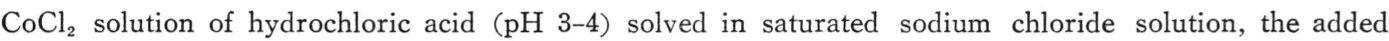
quantity to the delivered sodium chloride solution being in proportion: 0.02 volume of $0.01 \% \mathrm{CoCl}_{2}$ solution to 1 volume of a salt solution.

The added cobalt was continuously dropped into the cell at the place marked with X (Fig. 1), and the solution accumulated in the holes was collected for analysis at every 20 days. The analysis was also carried out for the anode solution.

Cobalt, iron, aluminium, magnesium, calcium, sulphate radical and sodium chloride were analyzed before and after the operation to measure the acccumulated quantities in the graphite, by means of the colorimetric method with nitroso $\mathrm{R}$ salt for cobalt; the gravimetric method for calcium, magnesium and aluminium; the colorimetric method with ammonium thiosulphate for iron; the Mohr's method for salt, and the volumetric method with sodium rozisonate for sulphate radical (Note 2 ).

For analysing the graphite the part shown in Fig. 3 was drilled with a drilling machine, and made to powder; the powder thus obtained was dipped into warm dilute hydrochloric acid for about a week, and analysis was carried out for its supernatant liquid.

\section{Experimental Results}

(1) Fig. 4 show changes of quantities of cobalt and sulphate radical, each contained in the solutions both in the anolyte and the graphite holes.

The content of cobalt in the solution obtained from the holes of graphite as $83 \%-95 \%$ of that of the cobalt accumulated in the anolyte. Little difference was found, however, between the cobalt contents in A and B graphites.

It is assumed that the accumulation is proportional to the porosity of the graphite. But the ion accumulation is controlled by not only simple circulation of electrolyte
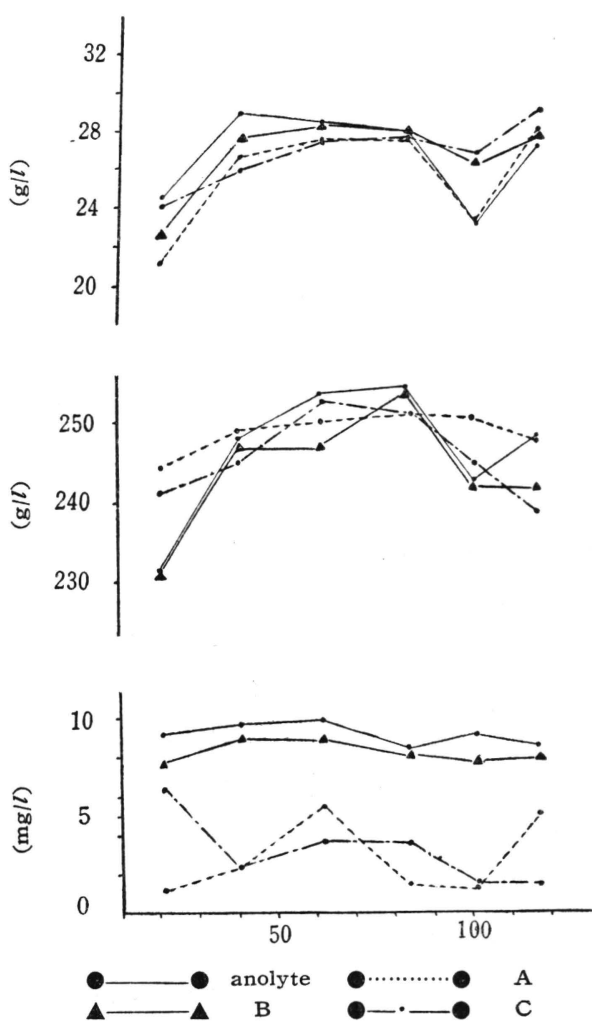

Fig. 4 Cobalt salt in the solution accum ulated in the graphite and content of sodium chloride, anp sodium sulphate as functions of time. 
but depends both on the ion condition in the solution and the structure of graphites, caused by manufacturing conditions.

Not much difference has been observed as to contents of both salt and sulphate radical among graphites A, B and C. Judging from the results, the influence of evaporation of the liquid accumulated in the graphite holes seems to be ignored.

Table 2 Magnesium Content in the Solution Accumulated in Graphite Holes

\begin{tabular}{|c|c|c|c|c|}
\hline Operation days & $\underset{(\mathrm{g} / l)}{\text { Anolyte }}$ & $\underset{(\mathbf{g} / l)}{\text { Graphite }} \mathrm{A}$ & $\underset{(\mathrm{g} / l)}{\text { Graphite }} \mathrm{B}$ & $\underset{(\mathrm{g} / l)}{\operatorname{Graphite}} \mathrm{C}$ \\
\hline 21 & 0.18 & 0.57 & 0.25 & 0.28 \\
\hline 41 & 0.31 & 0.50 & 0.36 & 0.31 \\
\hline 62 & 0.13 & - & - & - \\
\hline 84 & 0.19 & 0.37 & - & 0.17 \\
\hline 101 & 0.12 & - & 0.22 & 0.14 \\
\hline 117 & 0.25 & - & - & - \\
\hline
\end{tabular}

Table 3 Calcium Content in the Solution Accumulated in Graphite Holes

\begin{tabular}{|c|c|c|c|c|}
\hline Operation days & $\begin{array}{l}\text { Anolyte } \\
(\mathrm{g} / l)\end{array}$ & $\underset{(\mathrm{g} / l)}{\operatorname{Graphite}} \mathrm{A}$ & $\underset{(\mathbf{g} / l)}{\text { Graphite }} \mathrm{B}$ & $\underset{(\mathbf{g} / l)}{\operatorname{Graphite}} \mathrm{C}$ \\
\hline 21 & 0.16 & 7.95 & 2.02 & 1.93 \\
\hline 41 & 0.62 & 6.31 & 1.34 & 2.04 \\
\hline 62 & 0.23 & - & - & 一 \\
\hline 84 & 0.31 & 1.67 & 0.33 & 1.10 \\
\hline 101 & 0.13 & - & 0.45 & 0.82 \\
\hline 117 & 0.15 & - & - & - \\
\hline
\end{tabular}

Table 4 Iron Content in the Solution Accumlated in Graphite

\begin{tabular}{|c|c|c|c|c|}
\hline Operation days & $\begin{array}{c}\text { Anolyte } \\
(\mathrm{g} / l)\end{array}$ & $\underset{(\mathrm{g} / l)}{\operatorname{Graphite}} \mathrm{A}$ & $\underset{(\mathrm{g} / l)}{\text { Graphite }} \mathrm{B}$ & $\begin{array}{c}\text { Graphite } \\
(\mathrm{g} / l)\end{array}$ \\
\hline 21 & 0.013 & 0.298 & 0.029 & 0.053 \\
\hline 41 & 0.010 & - & - & - \\
\hline 62 & 0.005 & - & - & - \\
\hline 84 & 0.014 & 0.022 & 0.003 & 0.002 \\
\hline 101 & 0.043 & - & 0.009 & 0.009 \\
\hline 117 & 0.052 & - & - & - \\
\hline
\end{tabular}

(2) Tables 2, 3 and 4 show the changes of contents of magnesium, calcium and iron, in the liquids collected from the graphite holes and the anolyte as functions of time.

These results indicate that the magnesium content in the graphite $\mathrm{A}$ is slightly higher than those of $\mathrm{B}$ and $\mathrm{C}$ and 2-3 times as the concentration in the anolyte, while the magnesium contents in graphites $\mathrm{B}$ and $\mathrm{C}$ are both approximately $0.9-1.5$ times as the concentrations in the anolyte.

The calcium content in graphite $\mathrm{A}$ was about 5-50 times as that in the anolyte. The graphite $\mathrm{C}$ contained more calcium than B and about 2.5-12 times that in the anolyte while in the latter, it was about 1-12 times as that in the anolyte.

It is suggested that the porosity and the different manufacturing conditions caused such structual difference that the differences of the ion contents in graphites were brought about, though the detailed cause is still unknown.

(3) Tables 5 and 6 show the results of analysis of graphite before and after 120 days of operation.

Table 5 Analytic Values of Inorganic Components in the Graphite Before Use

\begin{tabular}{c|c|c|c|c|c}
\hline \hline Component & $\mathrm{SiO}_{2}$ & $\mathrm{Fe}_{2} \mathrm{O}_{3}$ & $\mathrm{Al}_{2} \mathrm{O}_{3}$ & $\mathrm{CaO}$ \\
\hline Content (\%) & $\begin{array}{c}0.04 \sim \\
0.05\end{array}$ & $\begin{array}{c}0.005 \sim \\
0.01\end{array}$ & $\begin{array}{c}0.009 \sim \\
0.013\end{array}$ & $\begin{array}{c}0.002 \sim \\
0.003\end{array}$ & $0 \sim 0.004$ \\
\hline
\end{tabular}


Table 6 Analytic Values of the Graphite After Use

\begin{tabular}{c|c|c|c}
\hline \hline Traphite & $\mathrm{A}$ & $\mathrm{B}$ & $\mathrm{C}$ \\
\hline Component $(\%)$ & & 5.51 & 5.12 \\
$\mathrm{H}_{2} \mathrm{O}$ & 1.76 & 2.30 & 2.00 \\
Total chlorine & 92.05 & 89.51 & 90.42 \\
Insoluble matter in acid & 0.005 & 0.006 & 0.006 \\
$\mathrm{Co}$ & 1.36 & 0.74 & 1.35 \\
$\mathrm{CaO}$ & 0.022 & 0.070 & 0.083 \\
$\mathrm{MgO}$ & 0.092 & 0.039 & 0.031 \\
$\mathrm{Fe}_{2} \mathrm{O}_{3}$ & 0.098 & 0.063 & 0.023 \\
$\mathrm{Al}_{2} \mathrm{O}_{3}$ & 1.42 & 0.82 & 0.71 \\
$\mathrm{SO}_{4}{ }^{2-}$ & & & \\
\hline
\end{tabular}

The values of Fig. 6 include the contents due to adhered anolyte. Table 7 gives the compositions recalculated by anolytic component at the time of dismantling the electrolytic cell and the porosity of the graphite or the adhered moisture on the graphite after use (Note 3 ).

Table 7 Calculated Values of Each Component Transferred from the Anolyte Adhered on the Graphite to the Graphite

\begin{tabular}{|c|c|c|c|}
\hline Component & Grahite & $\begin{array}{l}\text { Adjusted by moisture } \\
\text { content } \\
(\%)\end{array}$ & $\begin{array}{c}\text { Adjusted by porosity } \\
(\%)\end{array}$ \\
\hline Co & $\begin{array}{l}\mathrm{A} \\
\mathrm{B} \\
\mathrm{C}\end{array}$ & $\begin{array}{l}0.000017 \\
0.000027 \\
0.000025\end{array}$ & $\begin{array}{l}0.00006 \\
0.00008 \\
0.00007\end{array}$ \\
\hline $\mathrm{MgO}$ & $\begin{array}{l}\text { A } \\
\text { B } \\
\text { C }\end{array}$ & $\begin{array}{r}0.0009 \\
0.0015 \\
0.0014\end{array}$ & $\begin{array}{l}0.0037 \\
0.0047 \\
0.0042\end{array}$ \\
\hline $\mathrm{CaO}$ & $\begin{array}{l}\text { A } \\
\text { B } \\
\text { C }\end{array}$ & $\begin{array}{l}0.0008 \\
0.0013 \\
0.0012\end{array}$ & $\begin{array}{l}0.0032 \\
0.0041 \\
0.0036\end{array}$ \\
\hline $\mathrm{Fe}_{2} \mathrm{O}_{3}$ & $\begin{array}{l}\text { A } \\
\text { B } \\
\text { C }\end{array}$ & $\begin{array}{l}0.00016 \\
0.00026 \\
0.00024\end{array}$ & $\begin{array}{l}0.0006 \\
0.0008 \\
0.0007\end{array}$ \\
\hline $\mathrm{SO}_{4}{ }^{2-}$ & $\begin{array}{l}\mathrm{A} \\
\mathrm{B} \\
\mathrm{C}\end{array}$ & $\begin{array}{l}0.09 \\
0.14 \\
0.13\end{array}$ & $\begin{array}{l}0.34 \\
0.44 \\
0.39\end{array}$ \\
\hline
\end{tabular}

Table 8 Component of Anolyte

\begin{tabular}{c|c|c|c|c|c|c|c}
\hline \hline Component & $\mathrm{NaCl}$ & $\mathrm{SO}_{4}$ & $\mathrm{Co}$ & $\mathrm{Fe}_{2} \mathrm{O}_{3}$ & $\mathrm{CaO}$ & $\mathrm{MgO}$ & $\begin{array}{c}\text { Density } \\
/ 20^{\circ} \mathrm{C}\end{array}$ \\
\hline $\begin{array}{c}\text { Content } \\
(\mathrm{g} / l)\end{array}$ & 236.2 & 18.4 & 0.0036 & 0.034 & 0.17 & 0.20 & 1.17 \\
\hline
\end{tabular}

The component of anolyte at the time of dismantling the electrolytic cell is given in Table 8 .

It is obvious that there is little cobalt contained in the graphite anodes. Therefore the existence of cobalt is considered to be due to the added $\mathrm{CoCl}_{2}$ solution, which afterwards transferred and accumulation into the anolyte.

Approximate quantities of estimated accumulation of metallic components in comparison with those before use are 200-400 times for iron and 2-10 times for aluminum, respectively.

\section{Consideration}

(1) The differences in contents of cobalt, calcium, magnesium, iron, etc. in the solution accumulated in the holes of graphite appear to be due to the porosity and structual dissimilarity of graphites.

(2) A considerable quantity of calcium was contained in the graphite at the time of operation, but some white crystals were found in the solution, which were confirmed as calcium sulphate (dihydrate) by microscopic examination as shown in Fig. 5, but they disapeared in the electrolytic operation. The reason is still unkown, but it is suggested that it was caused probably by calcium already contained in the graphite.

(3) The contents of magnesium and iron accumulated in graphites are considerably high at the 
beginning of the operation, but they tended to fall gradually.

(4) It was not correct in the strict sense of the word to have applied the values of $22 \%, 25 \%$ and $28 \%$ respectively for the porosities in the caluculation of the contents due to the adhered anolyte in the inorganic components of the after-use graphite. They were adopted only as temporary miltipliers.

\section{Conciusion}

(1) An experiment was carried out on Allen Moore's KML-type electrolytic cell to find out the action of metallic components and their accumulation in the anodic graphite.

(2) Contents of cobalt in solutions accumulated in the holes of graphites varied with makers and time of electrolysis, but the content in graphites after-use remained almost identical for every graphites.

(3) Such metallic components as calcium, magnesium, iron, aluminium, etc. were also accumulated in the graphites. But the approximate ratio of the contents in the graphite after use to that before use was 200-300 times for calcium, 10-20 times for magnesium, 3-15 times for iron and 2-10 times for aluminium, respectively.

(4) Much has not yet been disclosed about the cause of accumulation of metallic components in the anodic graphite.

The authors would like to record their warm thanks to Prof. S. Oka, Tokyo University and to Prof. T. Matuno, Yokohama
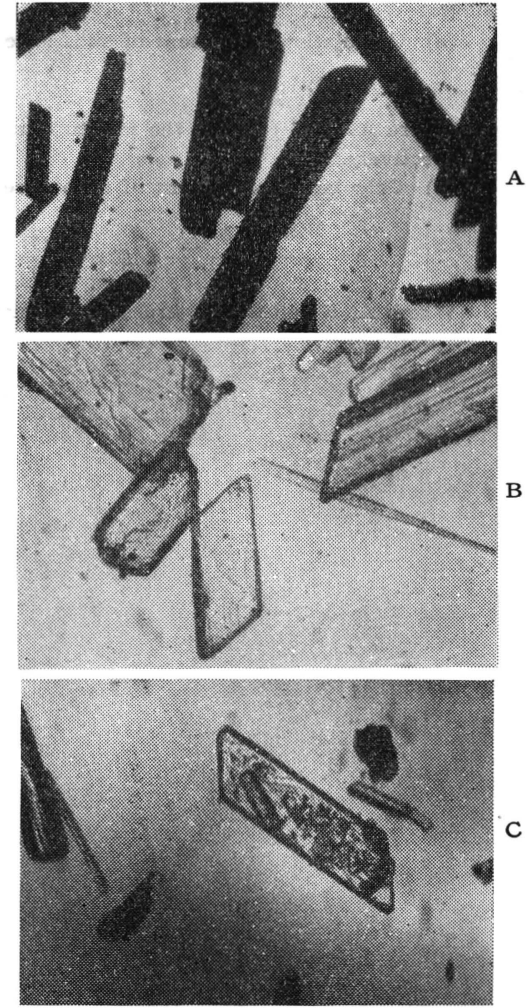

Fig. 5 Microscopic Photographs National University, for thier kind assistance during the experimet.

(Received March 31, 1958)

\section{Lterature :}

1) S. Fusioka, T.Moriya, Soda and Chlorine, 8, 134 (1957).

2 ) S. Hirano, J. Murayama, M. Kitahara, Japan Analyst, 5, 7 (1956).

3 ) O. Suzuki, C. Doi, T. Fukunaga, This Journal, 26, 135 (1958).

4) W.S. Joffe, Z. Electrochem. 42, 71 (1936).

Note 1

Different position of the experimental anodic graphite in the electrolytic cell seems to have caused differences in the concentration of every component in the anodic solution, and had some influence upon the experimental results. But a preparatory experiment as follows made it clear that little was the difference in $\mathrm{NaCl}$ concentration, positional influence was regarded as negligible, so the experiment was carried out with A, B and C corporations graphite allotted for No. 1-3 at random. Namely, the anolyte was taken out in glass tubes from graphite at the position No. 1-3, and $\mathrm{NaCl}$ concentration was analysed with the following result;

\begin{tabular}{|c|c|c|c|c|}
\hline Component & Times No. & No. 1 & No. 2 & No. 3 \\
\hline $\mathrm{NaCl}$ & First & 264.9 & 265.2 & 263.8 \\
\hline$(\mathrm{g} / l)$ & Second & 260.0 & 259.7 & 258.9 \\
\hline
\end{tabular}

Note 2

The reliability of the analysis.

The following were the values obtained from the repeated measurements for the same samples.

\begin{tabular}{c|c|c}
\hline \hline Component & Mean value (\%) & Standard deviation (\%) \\
\hline $\mathrm{Na}_{2} \mathrm{SO}_{4}$ & 9.34 & 0.005 \\
$\mathrm{Fe}_{2} \mathrm{O}_{3}$ & 0.022 & 0.001 \\
$\mathrm{CaO}$ & 0.0725 & 0.0004 \\
$\mathrm{MgO}$ & 0.037 & 0.001 \\
$\mathrm{NaCl}$ & 21.48 & 0.02 \\
$\mathrm{Co}$ & 0.00031 & 0.000009 \\
\hline
\end{tabular}


Note 3

(a) Calculation of content of substance transferred from anolyte on the basis adhered moisture on graphite : $x=C \times \frac{\mathrm{B}}{\mathrm{A}}(\%)$,

Where $\mathrm{A}, \mathrm{B}, \mathrm{C}(\%)$ are the moisture in anolyte, moisture adhered in grapite, and content of substance in anolyte respectively.

(b) Calculation of content of substance transferred from anolyte on the basis of porosity of graphite:

$$
x=\frac{W \times \frac{\mathrm{A}}{100} \times \frac{\mathrm{B}}{100}}{W} \times 100=\frac{A \times B}{100}(\%),
$$

Where A, B and C (\%) are the porosity of graphite, content of substance in anolyte and weight of graphite, respectively, 